\title{
The Analysis Appendiceal Neuroendocrine Neoplasia with Clinicopathological Findings
}

\section{Apendisyel Nöroendokrin Neoplazilerin Klinikopatolojik Bulgularla Analizi}

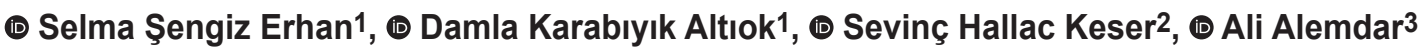 \\ 1 University of Health Sciences Turkey, Prof. Dr. Cemil Taşçıoğlu City Hospital, Clinic of Pathology, İstanbul, Turkey \\ 2University of Health Sciences Turkey, Kartal Dr. Lütfi Kırdar City Hospital, Clinic of Pathology, İstanbul, Turkey \\ 3University of Health Sciences Turkey, Prof. Dr. Cemil Taşçığlu City Hospital Health Application and Research Center, Department of General \\ Surgery, İstanbul, Turkey
}

\section{IIIIIIII| ABSTRACT}

Aim: Neuroendocrine cell groups seen in the appendix are defined as proliferative phenomenon similar to early neuroendocrine cell proliferation seen in other organs of the gastrointestinal tract. Neuroendocrine tumors (NET) account for $0.3-0.6 \%$ in in appendectomy materials. Rarely, appendicular collusion tumors have also been reported. Here, we presented appendiceal neuroendocrine neoplasms including rare cases.

Method: Appendectomy materials were reviewed between 2011-2020 and cases with neuroendocrine cell hyperplasia and NET were included in the study. The demographics of the cases, the size of the tumors, their localization, their dissemination, and their lymphovascular, perineural and mesoappendix invasions were evaluated, along with their clinical follow-ups.

Results: There were 4,433 appendectomy cases; 10 had neuroendocrine cell hyperplasia and 50 (1.1\%) had NET. Fourty-for cases were grade 1 and six of them were grade 2 . The mean diameter of tumors was $0.7 \mathrm{~cm}(0.1-2.5 \mathrm{~cm})$. In 36 cases, the tumor was localized in tip, in nine in body, and in five in tip + body. Tumor invaded submucosa in 14, muscle tissue in 17, subserosa/mesoapendix in 19. Two cases were in the collusion tumor group and low grade appendiceal mucinous neoplasia was detected as the secondary tumor. Two of the cases, whose clinical follow-ups were still continuing, died. Conclusion: In our study, the rate of NETs was slightly higher than the literature. Careful microscopic examination with accurate sampling is important in the detection of these tumors most of which are microscopic in size. Also, as in our study, two different tumors can take place simultaneously in the appendix.

Keywords: Appendix, collision tumor, neuroendocrine tumor

\section{|IIIIIIII| ÖZ}

Amaç: Apendikste görülen nöroendokrin hücre grupları, gastrointestinal sistemin diğer organlarında da görülen erken nöroendokrin hücre proliferasyonuna benzer proliferatif fenomen olarak tanımlanmaktadır. Nöroendokrin tümörler (NET) ise nadir olup, apendektomi materyallerindeki insidensi \%0,3-0,6 arasında değişmektedir. NET'e eşlik eden farklı histolojik tümörlerden oluşan nadir apendisyel kollüzyon tümörler literatürde bildirilmiştir. Çalışmamızda nadir özellikli olguları da barındıran apendiks yerleşimli nöroendokrin neoplazi olgularımızın klinikopatolojik bulgularını literatür bilgileri eşliğinde sunmayı amaçladık.

Yöntem: Çalışmamızda 2011-2020 yılları arasındaki apendektomi materyallerine ait kesitler gözden geçirildi. Nöroendokrin hücre hiperplazisi ve NET morfolojisine sahip olgular çalışmaya dahil edildi. Olguların demografik özellikleri, tümörlerin boyutu, lokalizasyonu, yayılımı, lenfovasküler, perinöral ve mezoapendiks invazyonları ile klinik takipleri değerlendirildi.

Bulgular: İncelenen 4.433 apendektomili olgu içinde 10’u nöroendokrin hücre hiperplazisi ve 50'si $(\% 1,1)$ NET tanısına sahipti. Kırk dört olgu grade 1, 6 olgu grade 2 idi. Ortalama tümör çapı 0,7 cm'di $(0,1-2,5 \mathrm{~cm})$. İki olguda tümör boyutu $2 \mathrm{~cm}$ ve üstündeydi. Olguların 36 'sında tümör apekste, dokuzunda gövdede ve beşinde apeks + gövdede lokalizeydi. Tümör olguların 14'ünde submukozaya, 17'sinde kas dokusuna, 19'unda subseroza/mezoapendikse yayılım göstermekteydi. Üç olguda lenfovasküler inazyon saptandı. İki olgu kollüzyon tümör grubunda olup, düşük dereceli apendisyel müsinöz neoplazi ikinci tümör olarak saptandı. Klinik takipleri devam eden olgulardan ikisi eks oldu.

Sonuç: Genellikle histopatolojik inceleme ile tanı alan NET’lerin oranı çalışmamızda literatürde belirtilen orandan hafif yüksekti. Çoğunluğu mikroskobik boyutta olan bu tümörlerin tespitinde doğru ve yeterli makroskopik örnekleme ile dikkatli mikroskobik inceleme önem taşımaktadır. Ayrıca çalışmamızda olduğu gibi, iki farklı tümör apendikste eş zamanlı yer alabilir.

Anahtar Kelimeler: Apendiks, kollüzyon tümör, nöroendokrin tümör

Address for Correspondence/Yazışma Adresi: Selma Şengiz Erhan, MD,

University of Health Sciences Turkey, Prof. Dr. Cemil Taşçığlu City Hospital, Clinic of Pathology, İstanbul, Turkey

E-mail: selmaserhan@hotmail.com ORCID ID: orcid.org/0000-0001-8810-8806

Received/Geliş Tarihi: 27.11.2020 Accepted/Kabul Tarihi: 13.12.2020

${ }^{\circ}$ Copyright 2021 by Turkish Society of Colon and Rectal Surgery

Turkish Journal of Colorectal Disease published by Galenos Publishing House. 


\section{Introduction}

Epithelial neoplasias of the appendix are rare, and they generally present with acute appendicitis and detected incidentally. ${ }^{1}$ Neuroendocrine cell groups that are observed in the appendix are described as proliferative phenomena that show similiarities to the early neuroendocrine cell proliferation also observed in other organs of the gastrointestinal tract. They are observed as small patchy groups, and most of them can be detected during microscopic examination. ${ }^{2}$ Neuroendocrine tumours (NETs), however, are rare, and they are observed between $0.3 \%$ and $0.6 \%$ of appendectomy cases. ${ }^{3}$ Although appendiceal collision tumours are quite rare, which include tumours with different histological types that accompany NETs, they have also been reported in the literature. ${ }^{4,5}$ Herein, we presented cases of neuroendocrine neoplasias, which were located in the appendix, including rare ones.

\section{Method}

In this study, we reviewed sections (immunohistochemical slides that were stained with haematoxylin and eosin) belonging to appendectomy materials in the pathology archive, which were sent to our department between 2011 and 2020. Patients with neuroendocrine cell proliferation and NET morphology were included in the study. Demographics of the patients (age and gender) and tumour size, localisation (tip, body and tip + body), depth of invasion (mucosa, submucosa, muscular propria and subserosa/mesoappendix), histological grade (grades I, II and III), surgical margin, lymphovascular and perineural invasions and clinical follow-ups were evaluated.

\section{Statistical Analysis}

Statistical analysis was conducted on the NET group. Data were completed by transferring them to the IBM SPSS Statistics programme. In data analysis, categorical variables are presented in the frequency distribution as number and percentage, and in the complementary statistics, numerical variables are presented as mean and standard deviation. The chi-square test was used to investigate the relationship between the categorical variables, and $p<0.05$ was accepted to indicate significance.

\section{Results}

\section{General Characteristics of the Neuroendocrine Neoplasia Group}

In this study, 4,433 appendectomy materials were examined. Sixty patients were allocated to the neuroendocrine neoplasia group, including 19 female patients and 4 male patients. The mean age was 33.5 (11-82) years.

Among these patients, one patient was diagnosed with neuroendocrine cell proliferation, and NETs in four patients were detected in the appendectomy material because their operations were not related to appendicitis.

\section{Cases Diagnosed as Neuroendocrine Cell Proliferation}

Ten patients were diagnosed with neuroendocrine cell proliferation (male, $\mathrm{n}=4$; female, $\mathrm{n}=6$ ). The mean age of these patients was $31.3 \pm 11.73(12-56)$ years. Among the lesions, some were smaller than $1 \mathrm{~mm}$ and some were microscopically detected; nine of them were localised in the tip and one was localised in the body. In three patients, the lesion was observed in the submucosa, and in eight patients, it was observed in the mucosa (Figure 1).

\section{Cases Diagnosed as NET}

In this study, 50 (1.1\%) patients were diagnosed with NET, including 15 female patients and 35 male patients. The mean age was $36.06 \pm 16.89$ (11-82) years. Four (0.09\%) were paediatric patients.

The mean tumour diameter was $0.7 \mathrm{~cm}(0.1-2.5 \mathrm{~cm})$. In $72 \%$ of the patients, the diameter of the tumour was $<1 \mathrm{~cm}$. In 2 patients, the tumour size was $\geq 2 \mathrm{~cm}$.

In the histopathological examination, the tumour was localised in the tip in 36 patients, in the body in 9 patients, and in the tip + body in 5 patients. The tumour disseminated into the submucosa in 14 patients, to the muscular tissues in 17 patients and to the subserosa/mesoappendix in 19 patients (Figure 2). Lymphovascular invasion was detected in three patients. Perineural invasion was not detected in any of the patients. No tumour was observed in the surgical margins. According to the Ki-67 proliferative indexes, 44 patients had grade I (88\%), while 6 patients had grade II (12\%).

While the two patients who were diagnosed of grade I NET belonged to the collision tumour group, the secondary

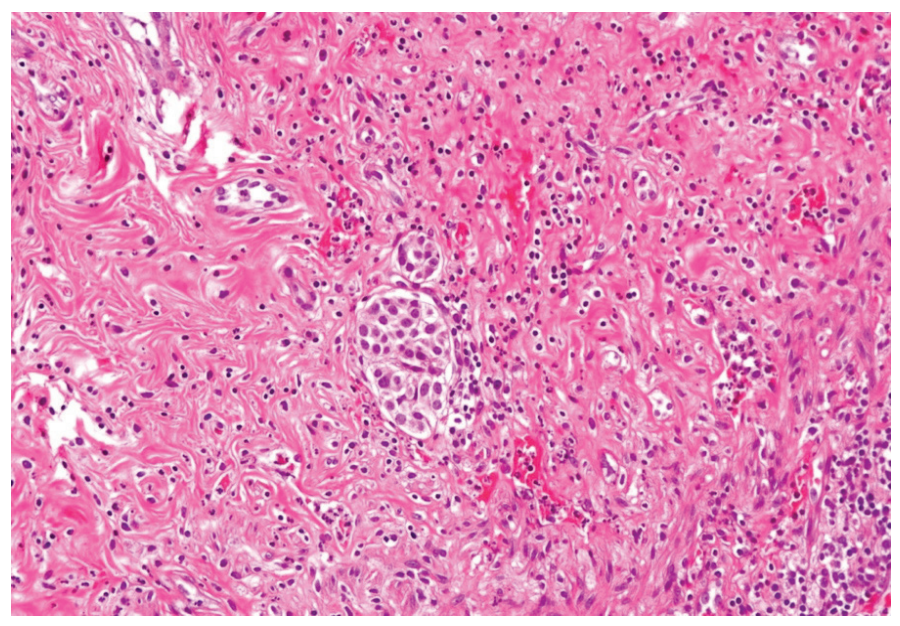

Figure 1. Neuroendocrine hyperplasia was detected in the submucosa through miscoscopic examination, haematoxylin and eosin staining, x200 
tumour that was accompanying them was a low-grade mucinous neoplasm (DDMN) (Figure 3). Both patients were 41 years old and female. Both tumours, $1.2 \mathrm{~cm}$ and 0.6

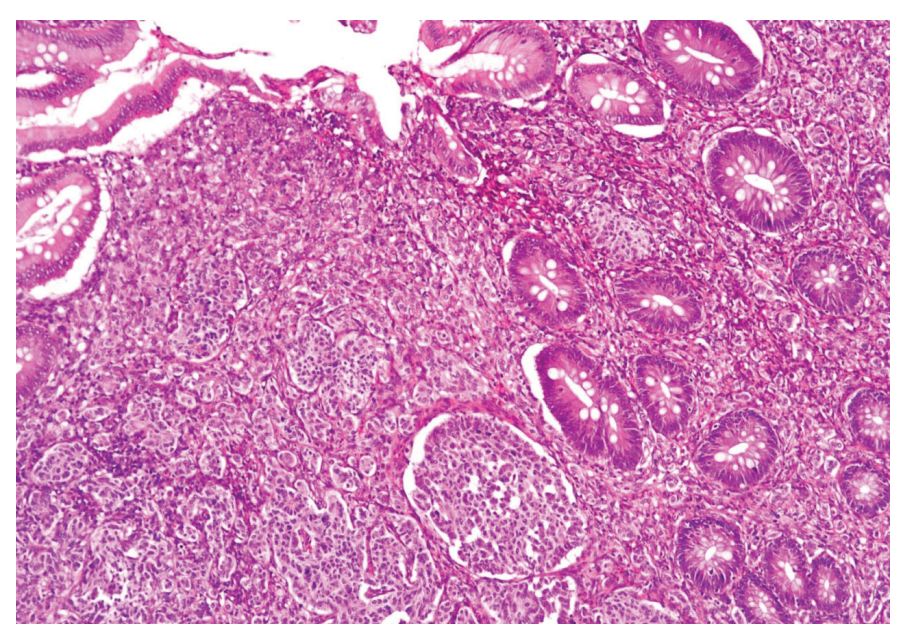

Figure 2. NET with solid islands of different sizes and uniform and round shape, showing infiltration among crypts, haematoxylin and eosin staining, x100

NETs: Neuroendocrine tumors $\mathrm{cm}$ in size, were localised in the body. Other patients with NETs had diverticula $(n=3)$ and acute appendicitis $(n=43)$ as additional findings.

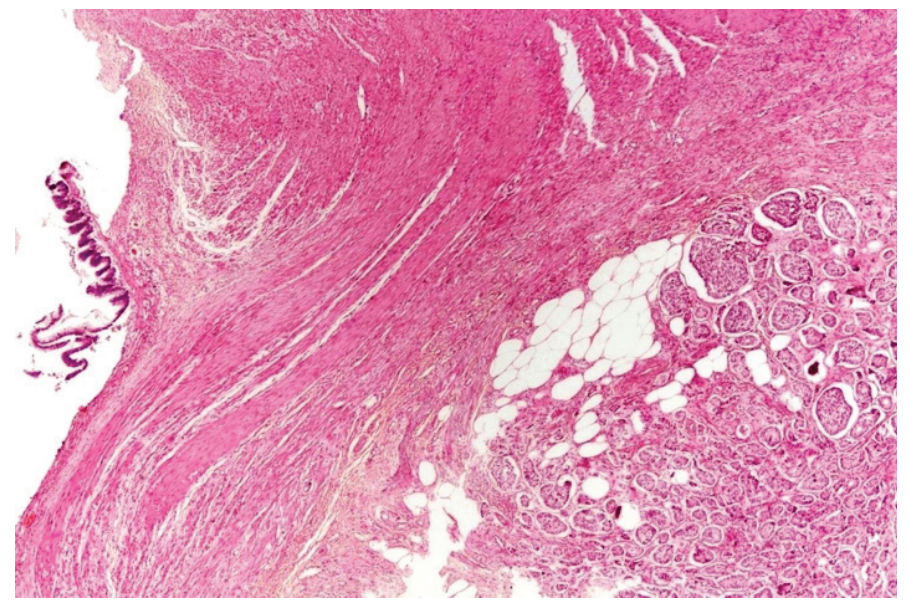

Figure 3. Low-grade mucinous neoplasia involving dysplastic epithelium (on the left) and collision tumour with a NET component that infiltrated into the muscular tissue (on the right), haematoxylin and eosin staining, $\mathrm{x} 40$

NET: Neuroendocrine tumor

Table 1. Clinicopathologic findings of patients diagnosed with neuroendocrine tumour

\begin{tabular}{|c|c|c|c|c|}
\hline & $\begin{array}{l}\text { Men } \\
\text { n (\%) }\end{array}$ & $\begin{array}{l}\text { Women } \\
\text { n (\%) }\end{array}$ & $\begin{array}{l}\text { Total } \\
\text { n (\%) }\end{array}$ & $\mathrm{p}^{*}$ \\
\hline \multicolumn{5}{|l|}{ Tumour localisation } \\
\hline Tip & $25(71.4 \%)$ & $11(73.3 \%)$ & $36(72 \%)$ & \multirow{3}{*}{0.218} \\
\hline Body & $5(14.3 \%)$ & $4(26.7 \%)$ & $9(18 \%)$ & \\
\hline Tip + body & $5(14.3 \%)$ & $0(0 \%)$ & $5(10 \%)$ & \\
\hline \multicolumn{5}{|l|}{ Tumour size } \\
\hline$<1 \mathrm{~cm}$ & $25(71.4 \%)$ & $11(73.3 \%)$ & $36(72 \%)$ & \multirow{2}{*}{0.891} \\
\hline$>1 \mathrm{~cm}$ & $10(28.6 \%)$ & $4(26.7 \%)$ & $14(28 \%)$ & \\
\hline \multicolumn{5}{|c|}{ Tumour dissemination (depth of invasion) } \\
\hline Submucosa & $11(31.4 \%)$ & $3(20 \%)$ & $14(28 \%)$ & \multirow{3}{*}{0.444} \\
\hline Muscular tissue & $10(28.6 \%)$ & $7(46.7 \%)$ & $17(34 \%)$ & \\
\hline Subserosa/mesoappendix & $14(40 \%)$ & $5(33.3 \%)$ & $19(38 \%)$ & \\
\hline \multicolumn{5}{|l|}{ Lymphovascular invasion } \\
\hline Positive & $2(5.7 \%)$ & $1(6.7 \%)$ & $3(6 \%)$ & \multirow{2}{*}{0.897} \\
\hline Negative & 33 (94.3\%) & $14(93.3 \%)$ & 47 (94\%) & \\
\hline \multicolumn{5}{|c|}{ Histological grade ${ }^{6}$ (according to the $\mathrm{Ki}-67$ proliferative index) } \\
\hline Grade I & 32 (91.4\%) & $12(80 \%)$ & $44(88 \%)$ & \multirow{2}{*}{0.348} \\
\hline Grade II & $3(8.6 \%)$ & $3(20 \%)$ & $6(12 \%)$ & \\
\hline \multicolumn{5}{|l|}{ Surgical margin } \\
\hline Positive & $0(0 \%)$ & $0(0 \%)$ & $0(0 \%)$ & \multirow{2}{*}{-} \\
\hline Negative & 35 (100\%) & $15(100 \%)$ & $50(100 \%)$ & \\
\hline
\end{tabular}

*Chi-square test 
According to the chi-square test, no significant relationship was found between gender and other parameters. No significant relationship was found between the tumour size and lymphovascular or perineural invasion $(\mathrm{p}>0.05)$ (Table 1). However, a significant relationship was found between the tumour size and its localisation, dissemination (depth of invasion) and histological grade $(\mathrm{p}<0.05)$. Moreover, the frequency to have tumours $>1 \mathrm{~cm}$ among of cases with the tumour located in the tip was significantly higher than that of cases with the tumour located in the tip or in the tip + body ( $\mathrm{p}=0.000$ ). The frequency to have tumours $>1 \mathrm{~cm}$ was significantly higher among cases with tumour dissemination into the subserosa/mesoappendix than among cases with tumour dissemination into the submucosa $(\mathrm{p}=0.008)$. The frequency of having tumour size $>1 \mathrm{~cm}$ was significantly higher among grade II cases than among grade I cases ( $\mathrm{p}=0.044)$ (Table 2).

Furthermore, while no significant relationship was found between the histological grade and tumour localisation ( $>0.05)$, a significant relationship was noted between the tumour grade and size, dissemination (depth of invasion) and lymphovascular invasion $(\mathrm{p}<0.05)$. This finding suggest that the frequency of having a grade II disease was significantly higher in patients with tumours $>1 \mathrm{~cm}$ than among patients with tumours $<1 \mathrm{~cm}(\mathrm{p}=0.044)$. The frequency of having a grade II disease was significantly higher for patients who had a tumour dissemination to the subserosa/mesoappendix than among patients with other dissemination types $(\mathrm{p}=0.045)$. The frequency for the patients in which lymphovascular invasion was not observed to have grade I was significantly higher than it is for patients in which lymphovascular invasion was observed （p=0.035）（Table 3).

\section{Treatment in the Neuroendocrine Neoplasia Group}

Among the 2 patients with a NET $>2 \mathrm{~cm}$, right hemicolectomy in addition to appendectomy was performed only in one of the patients. No additional surgical treatment was performed after the appendectomy for the other patients with NET and neuroendocrine cell hyperplasia.

\section{Survival Among the Neuroendocrine Neoplasia Group}

The mean duration of follow-up was 49.2 (1-102) months. Two patients died on the course of follow-up. While one of the patients died after 19 months, another died 1 month after the diagnosis because of intestinal ischaemia and perforation. Follow-up of other included patients are still on-going. No recurrence or metastases were detected at this time.

\section{Discussion}

Appendiceal neuroendocrine neoplasia originates from the enterochromaffin and enteroglucagon cells that are diffuse endocrine system cells located in the mucosa and

Table 2. Relationship between the tumour size and other parameters in patients with neuroendocrine tumour

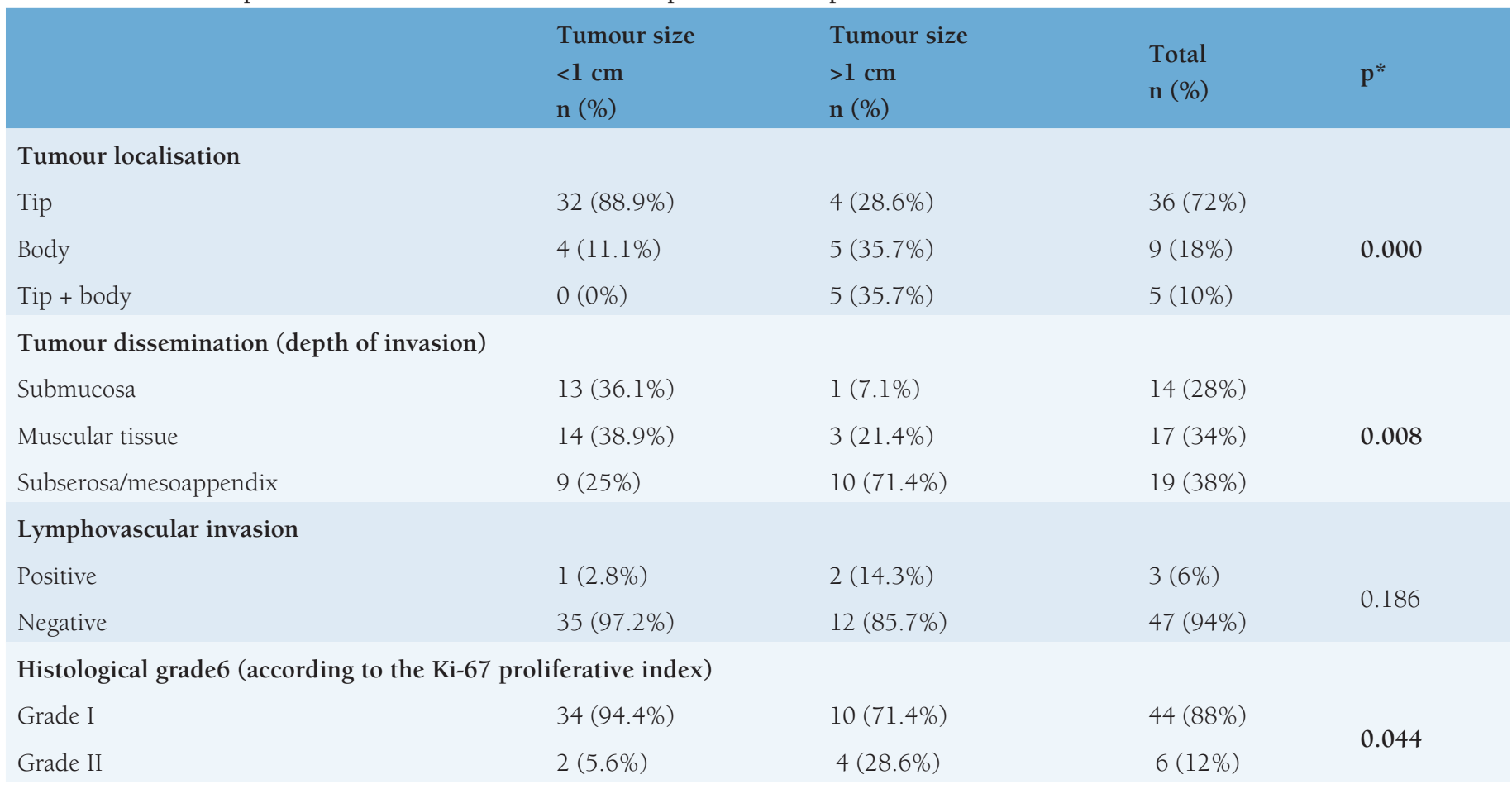

*Chi-square test 
submucosa. ${ }^{2,6}$ The proliferative phenomenon, which is described as early neuroendocrine cell proliferation, can usually be detected microscopically. However, there is no clear information regarding the underlying medical or genetic structure, which can predispose patients to this proliferation. $^{2}$ Appendiceal NETs are observed as the fifth most frequent type of NETs among gastrointestinal NETs, followed by the small intestine, rectum, pancreas and stomach. ${ }^{6}$ It is the most frequently observed tumour group among the primary tumours of the appendix, but its incidences vary between $0.3 \%$ and $0.6 \% .^{2,3,7}$ NETs are generally detected incidentally during histopathological examination of patients who underwent surgery for acute appendicitis. ${ }^{8,9}$ Thus, sufficient macroscopic sampling and careful microscopic examination are crucial to detect these tumours. In this study, neuroendocrine cells were of microscopic size and were detected incidentally. In addition, the frequency of NETs was higher than that reported in the literature. These findings show the importance of microscopic and macroscopic examinations.

These tumours, which can be observed in every age group and mostly on women, more often occur in the second and third decades of life. ${ }^{9}$ In this study, they were more often detected in male (70\%) patients, which is different from what the literature suggested. NET may be found among appendiceal epithelial tumours in the paediatric group; although no study reported its frequency, it is a rare phenomenon just as NETs in adults. ${ }^{10}$ In this study, only a few patients in the paediatric age group had NETs.

NETs may be missed easily in radiological examinations because of their small sizes. Most of these tumours are localised in the tip, and $80 \%$ are $<1 \mathrm{~cm}$ in size., ${ }^{2,6,8}$ The tumour localisation and sizes in this study were compatible with literature data.

NETs are graded according to the mitotic activity and Ki67 proliferative index. ${ }^{11}$ According to the World Health Organization, NET grade I is designated by a mitotic count of $<2$ per $2 \mathrm{~mm}^{2}$ (40x magnification) and Ki- $67<3 \%$, NET grade II by a mitotic count of $2-20$ per $2 \mathrm{~mm}^{2}$ and Ki-67 $3 \%-20 \%$, NET grade III by a mitotic count of $>20$ per $2 \mathrm{~mm}^{2}$ and Ki-67 $>20 \%$ and neuroendocrine carcinoma (NEC) by a mitotic count of $>20$ per $2 \mathrm{~mm}^{2}$ and Ki-67 $>20 \%$. In $81 \%-91 \%$ of the cases, the Ki- 67 ratio of the tumours was $<3 \%$, which were found to be grade I tumours $(2,6)$. Grade II tumour diagnosis is less frequent (9\%-14\%). Mixed neuroendocrine-nonneuroendocrine neoplasm (MINEN), which is in the NET grade III, NEC and collision tumour groups, is quite rarely found in the appendix. ${ }^{6,712}$ NET cases that were included in our study had grade I and grade II differentiations. No patients were diagnosed with grade III, NEC or MINEN.

Collision tumours are described as the clonal proliferation of two histologically different tumour types that are independent of each other and consequently regarded to

Table 3. Relationship between the grade and other parameters in patients diagnosed with neuroendocrine tumour

\begin{tabular}{|c|c|c|c|c|}
\hline & $\begin{array}{l}\text { Grade I } \\
\text { n (\%) }\end{array}$ & $\begin{array}{l}\text { Grade II } \\
\text { n (\%) }\end{array}$ & $\begin{array}{l}\text { Total } \\
\text { n (\%) }\end{array}$ & $\mathrm{p}^{*}$ \\
\hline \multicolumn{5}{|l|}{ Tumour localisation } \\
\hline Tip & $34(77.3 \%)$ & $2(33.3 \%)$ & $36(72 \%)$ & \multirow{3}{*}{0.061} \\
\hline Body & $6(13.6 \%)$ & $3(50 \%)$ & $9(18 \%)$ & \\
\hline Tip + body & $4(9.1 \%)$ & $1(16.7 \%)$ & $5(10 \%)$ & \\
\hline \multicolumn{5}{|l|}{ Tumour size } \\
\hline $1 \mathrm{~cm} \downarrow$ & $34(77.3 \%)$ & $2(33.3 \%)$ & $36(72 \%)$ & \multirow{2}{*}{0.044} \\
\hline $1 \mathrm{~cm} \downarrow$ & $10(22.7 \%)$ & $4(66.7 \%)$ & $14(28 \%)$ & \\
\hline \multicolumn{5}{|c|}{ Tumour dissemination (depth of invasion) } \\
\hline Submucosa & $14(31.8 \%)$ & $0(0 \%)$ & $14(28 \%)$ & \multirow{3}{*}{0.045} \\
\hline Muscular tissue & $16(36.4 \%)$ & $1(16.7 \%)$ & $17(34 \%)$ & \\
\hline Subserosa/mesoappendix & $14(31.8 \%)$ & $5(83.3 \%)$ & $19(38 \%)$ & \\
\hline \multicolumn{5}{|l|}{ Lymphovascular invasion } \\
\hline Positive & $1(2.3 \%)$ & $2(33.3 \%)$ & $3(6 \%)$ & \multirow{2}{*}{0.035} \\
\hline Negative & $43(97.7 \%)$ & $4(66.7 \%)$ & $47(94 \%)$ & \\
\hline
\end{tabular}

*Chi-square test 
be in the same tumour group that includes NETs and lowgrade mucinous neoplasia., ${ }^{4,512}$ These tumours, which are observed as neoplasia that are independent of each other, but still adjacent, are quite rare and usually reported as case reports. Because they are rarely observed, there is no recommended method for patient management regarding postoperative follow-up. High emphasis is placed on radiological screening with regular intervals and on tumour indicators if they increased before the surgery., ${ }^{5,12}$ In our study, two patients were diagnosed with collision tumour. The secondary neoplasia that accompanied NET was a DDMN. In the literature, DDMNs are mostly observed in women. ${ }^{13}$ While NETs were more often observed in men in this study, both NET cases were found in women. Owing to the negative surgical margins and low recurrence rates of this tumour type, clinical follow-ups were regarded sufficient for the postoperative management.

Appendectomy is sufficient for the treatment of NETs $<1$ $\mathrm{cm}$ and with negative surgical margin. Right hemicolectomy is the recommended additional treatment for tumours $>2$ $\mathrm{cm}$ with lymphovascular invasion or tumours that showed deep infiltration in the mesoappendix, which are among the parameters associated with prognosis. ${ }^{1,8,9}$ In this study, some patients had tumours $>2 \mathrm{~cm}$, and some had lymphovascular and mesoappendix invasion. However, hemicolectomy was performed in patient with tumour $>2 \mathrm{~cm}$. For other patients who were clinically followed, no recurrence or metastases were detected during their follow-ups.

The tumour size and localisation, histological grade, lymphovascularinvasion and infiltration in themesoappendix are among the prognostic factors of appendiceal NETs. ${ }^{2,7,14}$ Having tumour $>2 \mathrm{~cm}$, lymphovascular invasion and mesoappendix infiltration may increase the probability of nodal metastases. While no clear relationship was shown between tumour localisation and prognosis, tumours localised in the surgical margins of the appendix may be appropriate candidates to prove such relationship in terms of incomplete excision and recurrence. ${ }^{7}$ In previous studies, while most Grade I and II cases showed a more silent clinical picture, a more common picture regarding the illness may be observed in a smaller number of patients. ${ }^{15}$ While a study reported that the proliferative index is not correlated with survival ${ }^{16}$, another study reported that the metastatic potential may be related to the Ki- 67 proliferative index. ${ }^{17}$ In the present study, lymph node metastasis was detected in patients with $\mathrm{Ki}-67$ proliferative index over $2 \%$. This emphasises that the probability of metastasis may increase as the grade increases and that these cases should be followed up more closely. Only a few studies in the literature have evaluated the relationship between prognostic parameters. A study did not found a correlation between the mesoappendix infiltration and tumour size. ${ }^{18}$ In this study, we examined the relationship between sex, tumour size, histological grade and other tumour parameters. A significant relationship was detected between the tumour size and localisation, dissemination (depth of invasion) and histological grade. Tumours $>1 \mathrm{~cm}$ were more frequently localised in the tip, more frequently showed subserosa/mesoappendix infiltration, which differs from the literature, and had more grade II histological differentiation. In addition, a significant relationship was detected between the grade's tumour size and its dissemination (depth of invasion) and lymphovascular invasion. Accordingly, grade II differentiation was often detected in tumours $>1 \mathrm{~cm}$ and in tumours that showed subserosa/mesoappendix infiltration. Moreover, tumours without lymphovascular invasion were mostly grade I tumours.

The prognosis of the NETs is usually very good, and the 5-year survival rate varies between $95 \%$ and $100 \%{ }^{6}$ In our study, except for the 2 patients who died 1 month and 24 months after their diagnosis, other patients are still on follow-up.

\section{Conclusion}

In conclusion, the frequency of NETs that were diagnosed by histopathological examination in this study was slightly higher than that in the literature. Our two cases of collision tumour diagnosis, which consisted of NET accompanied by low-grade mucinous neoplasia, were among the quite rare cases in the literature. Two different tumours can coexist in the appendix, as may be seen in our study. The possibility of a NET that may be accompanying another tumour, as we detected in the appendix, and the possibility of another tumour in the appendix in which NET had been detected should always be considered.

\section{Ethics}

Ethics Committee Approval: University of Health Sciences Turkey, Prof. Dr. Cemil Taşşıŏlu City Hospital (number: 48670771-514.10).

Informed Consent: Obtained.

Peer-review: Externally and internally peer reviewed.

\section{Authorship Contributions}

Concept: S.Ş.E., D.K.A., Design: S.Ş.E., D.K.A., S.H.K., A.A., Data Collection or Processing: S.Ş.E., D.K.A., A.A., Analysis or Interpretation: S.Ş.E., S.H.K., A.A., Literature Search: S.S..E., D.K.A., Writing: S.S..E., D.K.A., S.H.K., A.A. Conflict of Interest: No conflict of interest was declared by the authors.

Financial Disclosure: The authors declared that this study received no financial support. 
Erhan et al.

\section{References}

1. Tang LH. Epithelial neoplasms of the appendix. Arch Pathol Lab Med 2010;134:1612-1620.

2. Adsay NV, Klimstra DS. Neuroendocrine tumors of the gastrointestinal and pancreatobiliary tracts. In Odze RD, Goldblum JR, eds. Odze and Goldblum's Surgical Pathology of the GI tract, Liver, Biliary Tract and Pancreas. Third edition, Elsevier Saunders 2015:803-820.

3. Unver N, Coban G, Arıcı DS, Buyukpinarbasilı N, Gucin Z, Malya FÜ, Onaran OI, Topalan K. Unusual Histopathological Findings in Appendectomy Specimens: A Retrospective Analysis of 2047 Cases. Int J Surg Pathol 2019;27:142-146.

4. Ekinci N, Gün E, Avcl A, Er A. Coexistence of low grade mucinous neoplasm and carcinoid (collision tumor) within multiple appendiceal diverticula: A case report. Turk J Surg. 2018;31:1-3.

5. Tan HL, Tan GH, Teo M. Two rare cases of appendiceal collision tumours involving an appendiceal mucinous neoplasm and carcinoid. BMJ Case Rep 2016;1:1-3

6. Couvelard A, Perren A, Sipos B. Apendiceal neuroendocrine neoplasm. WHO Classification of tumours Digestive System Tumours. 5th edit. World Health Organization 2019.p.152-155.

7. Moris D, Tsilimigras DI, Vagios S, Ntanasis-Stathopoulos I, Karachaliou GS, Papalampros A, Alexandrou A, Blazer DG, Felekouras E. Neuroendocrine neoplasms of the appendix: A review of the literature. Anticancer Research 2018;38:601-612.

8. Abdelaal A, Ansari WE, Al-Bozom I, Khavar M, Shahid F, Aleter A, Abunuwar MR, El-Menyar A. Frequency, characteristics and outcomes of appendicular neuroendocrine tumors: A cross-sectional study from an academic tertiary care hospital. Ann Med Surg 2017;21:20-24.

9. Barut B, Gönültaş F. Carcinoid tumors of appendix presenting as acute appendicitis. Ulus Travma Acil Cerrahi Derg 2019;25:510-513.
10. Wu Hao, Chintagumpala M, Hicks J, Nuchtern JG, Okcu F, Venkatramani R. Neuroendocrine tumor of the appendix in children. J Pediatr Hematol Oncol 2017;39:97-102.

11. Klimstra DS, Klöppel G, La Rossa S, Rindi G. Classification of neuroendocrine neoplasms of the digestive system. WHO classification of tumours editorial board. Digestive system tumours. 5th edit. Lyon (France) 2019:16-19.

12. Singh NG, Mannan AASR, Khvic M, Nur AM. Mixed adenocarcinomacarcinoid (Collision tumor) of the appendix. Med Princ Pract 2011;20:384386.

13. Xiao J, Li P, Liu W.Analysis of clinical characteristics of low-grade appendiceal musinous neoplasm (LAMN): A retrospective cohort study of 51 LAMN patients J Invest Surg 2020;6:1-7.

14. Couvelard A, Perren A, Sipos B. Appendiceal neuroendocrine neoplasms. WHO classification of tumours editorial board. Digestive system tumours. 5th edit. Lyon (France) 2019:152-155.

15. Mullen JT, Savarese DM. Carcinoid tumors of the appendix: A populationbased study. J Surg Oncol 2011;104-41-44.

16. Volante M, Daniele L, Asioli S, Cassoni P, Comino A, Coverlizza S, De Giuli P, Fava C, Manini C, Berruti A, Papotti M. Tumor staging but not grading is associated with adverse clinical outcome in neuroendocrine tumors of the appendix: A retrospective clinical pathological analysis of 138 cases. Am J Surg Pathol 2013;37:606-612.

17. Grozinsky-Glasberg S, Alexandraki KI, Barak D, Doviner V, Reissman P, Kaltsas GA, Gross DJ. Current size criteria fort he management of neuroendocrine tumors of the appendix: Are they valid? Clinical experience and review of the literature. Neuroendocrinology 2013;98:31-37.

18. Alexandraki KI, Kaltsas GA, Grozinsky-Glasberg S Chatzellis E, Grossman AB. Appendiceal neuroendocrine neoplasms: diagnosis and management. Endocrine-Related Cancer 2016;23:R27-R41. 